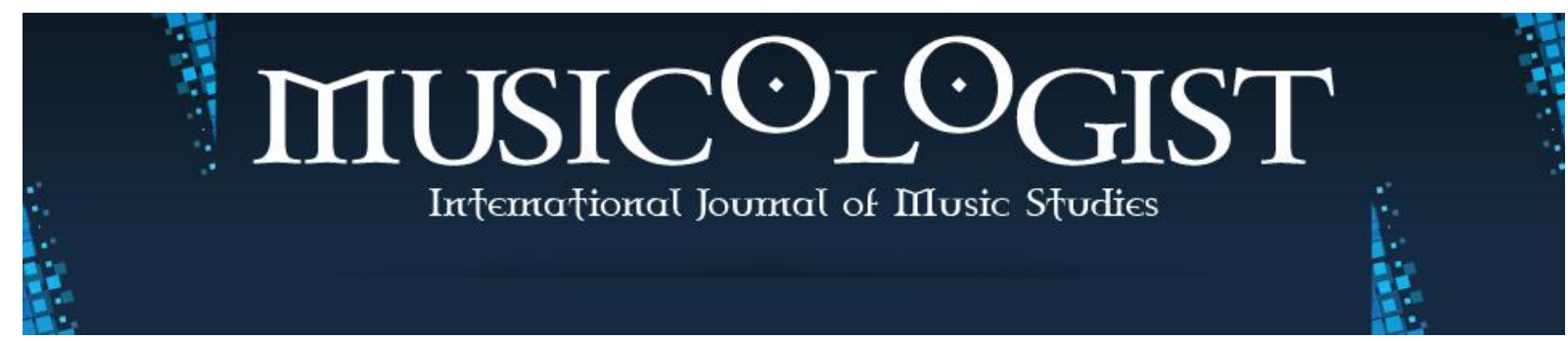

Trabzon University State Conservatory (C) 2017-2020

Volume 4 Issue 2 December 2020

Research Article

Musicologist 2020. 4 (2): 248-261

DOI: $10.33906 /$ musicologist.752422

CHINEDUM N. OSINIGWE

Ajayi Crowther University, Nigeria

cn.osinigwe@acu.edu.ng

orcid.org/0000-0003-2101-1916

\title{
Igbo Popular Music: A Historical and Sociological Discourse with the Intent of Redefining Its Musical Typologies Since 1960
}

\begin{abstract}
In Nigeria, music making has been the most dynamic and evolving process, involving all forms of musical genres - traditional, religious and popular. Music does have a significant cultural and sociological role, especially among its many ethnic groups, whereby it is employed in every facet of their socio-cultural existence, from childhood to adulthood respectively. This study examines the Igbo popular musical genre in Nigeria through its creative forms (highlife and other hybridized forms), exhibited within the period from 1960 up to the present. The main objective of this study is to capture all musical typologies within the period stipulated and tag them, using sociocultural parameters, such as language, age, group philosophy, musical form, etc. It adopted descriptive and socio-musicological approaches in evaluating the musical trends through periodized format and also using the socio tagging system as its conceptual framework. The following musical typologies (Égwú Nñùtá, Égwú Ìkwokilìkwo, Égwū Oggbàrà-ọfūù, and Égwú A gwàrà ggwa) were, however, discovered and tagged appropriately in the course of the study for easy reference, recognition, and for ethnic identity.
\end{abstract}

\section{KEYWORDS}

Igbo popular music

Typologies

Tagging

Periodized

Hybridized 


\section{Introduction}

Popular music is an extension of several musical typologies, which could be indigenous or acculturated, incorporating both local and foreign elements. As cities or urban centres began to develop in Nigeria (especially in the pre-colonial and post-colonial eras), different musical styles were advanced by ethnic groups through their various representatives in the urban centres. Some of these musicians had been exposed to other cultures (Western, Islamic, and others) and this greatly influenced their music. Commenting on the acculturation of Nigerian popular music, Obidike remarks that:

“... contact with foreign musical cultures during the nineteenth and first half of the twentieth century resulted in influences and counter influences, which created a big shift in the musical practices of most African peoples in terms of typologies, structures and performance practices" (2012:187).

Contemporary music of the Igbo people in Nigeria is subdivided into four (4) distinct categories: traditional music (égwú odi-n'àlà), church music (égwú ndi-úkà), art music (égwú èdèrèdè), and popular music (égwú ná-ewù-ewù). Within the context of this paper, Igbo popular music is discussed from the linguistic perspective (that is, 'Igbo' as a language) and secondly, the word 'Igbo' signifying an ethnic identity, race or people (Nwoye 2011: 305). Igbo popular music and its musicians represent the ethnic stock of people who are indigenes of the South-east and parts of the South-south geopolitical zones of Nigeria consisting of Abia, Anambra, Ebonyi, Enugu, Imo and some parts of Delta, Edo and Rivers States. However, this study focuses on Igbo popular music as expressed within the highlife genre (just like other ethnic-based highlife forms in Nigeria, such as Yoruba, Edo, Efik, Isoko, etc), through a historical and sociological analysis of the evolution of the music genre from past to present (1960 to date). According to Emielu (2011), Igbo highlife is a product of an intersection of local and global socio-cultural and socio-musical perspectives.

It has been established through historical analysis that the popular music scene in Nigeria evolved through three (3) distinctive musical eras or periods, which propagated musical styles derived from different cultures (African, Caribbean, European, and American). The first of the musical eras was the period during which highlife music evolved (OmibiyiObidike, 2012; Vidal, 2012; Oikelome 2012), which was around 1940, the second was in 
the mid-sixties when highlife music was declining and popular musicians (especially around the western region) searched and discovered other musical forms or styles that appealed to their audience - musical styles such as soul, jazz, and pop music (Obidike, 2012). Lastly, during the millennium era when Nigerian artistes (especially the younger generation) developed what is presently known as 'Naija Music' (Adeola 2001; Olusoji, 2011), a synthesis of diverse musical forms or styles (hip-hop, rap, dance hall, raga, soukous, etc) creatively fused and blended with local elements such as language (code switching) and instrumentation. They came up with hybrids such as Hip-life (fusion of highlife and hip-hop), Igbo rap, and various remixes of old tunes (Olusoji, 2011). From these three (3) musical periods, the one that evolved an Igbo musical typology was the highlife music (1940) which gave birth to 'İkwọ́kilìkwọ́’ music, a version of Igbo highlife tagged 'Igbo native blues'. Other musical periods, such as the soul-pop era (1970) and naija music era (2000), appeared to lack the identifiable musical typologies that are widely known and attributable to contemporary Igbo popular music. The foregoing is best illustrated in the diagram below:

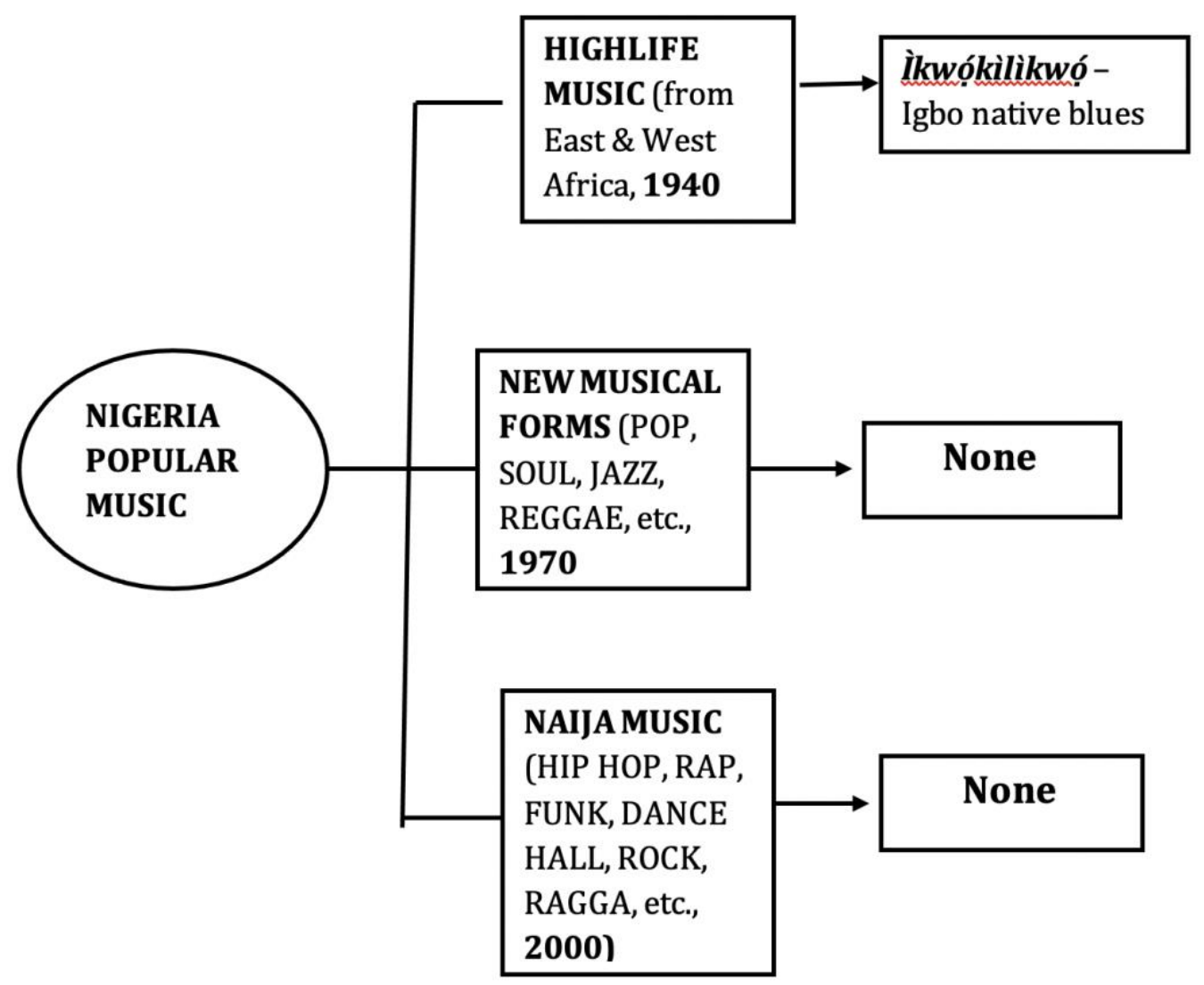

Figure 1. Illustration showing different musical periods in Nigeria Popular Music scene 
From the illustration above, periods that came after the highlife music era apparently did not witness any creation of Igbo musical typologies, and this lacuna or gap is what the present study wishes to address.

The primary data for this study was generated through the unstructured oral interviews, non-participant observation, audio-visual recordings and personal phone interviews with stake holders in the music industry. The secondary data, however, was sourced through existing literatures - journals, online publications and doctoral dissertations. This study is approached from a qualitative perspective and adopts a descriptive method of analysis, whereby all relevant elements regarding 'Igbo popular music' are presented in a more historical and sociological manner for easy assimilation and understanding.

\section{Concept of Social Tagging}

The conceptual framework, on which the contextual structure of this study is hinged, the term 'musical tagging', is an adaptation of the concept of 'social tagging' - a term used primarily in the world of Digital Information (DI). In his treatise, Studying Social Tagging and Folksonomy: a Review and Framework', Trant (2009) described Social Tagging as the practice of publicly labeling or categorizing resources in a shared on-line environment. The main positive thrust of this concept is that searching tags enable the discovery of relevant resources, and the social relationships that develop among taggers become a means of information discovery among themselves (Marlow et al., 2006a as cited in Trant (2009). The framework of the aforementioned concept (though related to the digital world), fits in properly into the analytical framework of this study, especially regarding the search for suitable labels or tags for musical typologies churned out by different generations of Igbo popular musicians (from 1960-till date) and within the contemporary music scene in Nigeria. These musical tags bear the ethnic garb of the Igbo identity (in terms of language) and are succinctly categorized, based on cultural indices such as age, musical maturation, periodic styles, and other necessary parameters.

\section{IGBO Contemporary Musical Styles since Pre-Independence}

Popular music is an offshoot of several musical typologies, which could be indigenous or acculturated, incorporating both local and foreign elements. Most popular musical styles or genres in the Nigerian music scene evolved through various contributions by musicians who hailed from different ethnic backgrounds in Nigeria and who, in turn, have 
advanced and developed these musical styles or genres over time. Historical accounts of popular music in Nigeria by different scholars, Oikelome, 2001; Piero, 2003; Ekwueme, 2004; Obi, 2005; Olusoji, 2011; Fiofori, 2011; Vidal, 2012; and Obidike, 2012; validate the fact that the music genre did evolve from various traditional music practices of ethnic groups through the means of acculturation and influences from external cultures (Western and Arab).

Euba, as cited in Oikelome (2011), categorized Nigerian popular music genres into three (3): 1. musical styles that evolved from pure Western pop (country music, ballroom dance, jazz music, etc); 2 . musical styles created through the means of acculturation that is, use of both African and Western musical elements (highlife and afro beat); and 3. musical styles popularized by certain ethnic groups in Nigeria such as, Igbo, Yoruba, and Edo (jùjú, wákà, àpàlà, and ikwọ́killìkwọ́). The third category, however, depicts the highlife style of Igbo popular music with its resultant typology - Ikwọ́kilikwọ́ at the earliest stage of the evolution of the music genre in the mid-sixties. The main objective of this study is to identify key musical styles/ typologies exhibited by prominent Igbo popular musicians right from the post-independence era to the twenty-first century and to tag them appropriately with nomenclatures that are derived from the mother tongue - Igbo. The tagging of these musical styles, apart from enabling ease of referencing, equally facilitates a sense of socio-cultural identity within the already polarized contemporary music scene in Nigeria. This present feat was seen to have been achieved among other ethnic groups, especially the Yoruba popular musicians, who developed several musical typologies/ styles that held sway within the pre-independence era to the present era (Omojola, 2006; Olatunji, 2007; Olusoji, 2011; Omibiyi-Obidike, 2012; Oikelome, 2012; Vidal, 2012). The civil war that was experienced between 1967 and early 70's by the Igbo race accounted for the periodic gap of musical outputs by Igbo musicians' between 1960-1975 (OmibiyiObidike, 2012).

The contemporary music of the Igbo people in Nigeria evolved through the following musical genres: traditional music (égwú odi-n'àlà), church music (égwú ndi-úkà), art music (égwú èdèrèdè), and popular music (égwú ná-ewù-ewù) respectively. This evolution process was replicated in other ethnic groups, but at different periods, especially during the advent of the colonial rule in Nigeria. The evolution experiences from one ethnic group to another differed based on cultural idiosyncrasies and dogmatic 
tendencies, displayed by indigenes during the process of acculturation, that is, imposition of western culture on our traditional norms and values.

The Igbo traditional music (égwú odi-n'àlà), like that of its counterparts, existed before the advent of colonial administration in Nigeria. It is deeply rooted in the cultural practices of the people and usually accompanies social and religious (ritual) ceremonies with various forms of dances. The instrumentation within the musical genre is highly percussive in nature and thus helps to initiate the desired rhythm, which facilitates the singing or dancing activities. The melodic instruments are mostly used for specialized kinds of music, either for ritual ceremonies, or for court music. According to Osigwe (2016), Igbo traditional musical instruments are categorized into the following families:

1. Membranophones - involves all sizes and shapes of cylindrical drums (igba)

2. Idiophones (melodic rhythms) -Ekwe na Ikwemgḅo (slit drums), Ngedelegwu (xylophone)

3. Idiophones (non-melodic rhythms) - Alo na Ogene (conical shaped iron gong),Egede (tiny bells worn around the waist), Uyọ, Ishaka na Ekpili (rattles \& shakers), Ọpokọlo (wood clappers), Agbe (beaded gourd)

4. Chordophones - Une na Ụbo-akwara (plucked bow), Ụbo-aka (thumb piano)

5. Aerophones - Odu Enyi (elephant tusk), Opi (horns), Oja (wooden flute)

Church music (égwú ndi-úkà) came as a result of the contact between the Igbo and the Church missionaries. Those who were converted to Christianity were educated on how to read, write, and speak the language of the missionaries. Christian schools were established alongside churches, and many Igbo converts were indoctrinated into believing that all indigenous songs and dances were evil and, therefore, should be done away with. Traditional musical instruments, being termed as unholy and evil, were not allowed in Christian worships. Only portable organ or the harmonium, were admitted for use in Christian worship. Western hymns were translated into Igbo using the same metre of the original Western verses and sung to the same tunes. These tunes became popular household melodies in Christian homes. However, the term 'egwu ndi choochi or ndi-uka' came to existence, as a result of using Western metric tunes to sing the Igbo translated hymns (Okafor, 1997). According to Ekwueme, "unexpected tonal inflections often occur 
in these hymns, giving rise to unintended meanings, especially as several different stanzas are sung to the same tune" (2004: 210-212). Many notable Igbo Church musicians or Choirmasters/Organists, who received their trainings from the colonial masters, advanced the fusion of Igbo Christian texts with the Western style of notation and documentation. These activities helped immensely in developing the musical genre of Art Music from the historic past up to the present day. Examples of these Church musicians were: Nelson E. Okoli, Harcout Whyte, W.W.C Echezona, Felix Nwuba, and Lazarus Ekwueme.

Lastly, the popular music genre (égwú ná-ewù-ewù) evolved as a result of contact with urban life. Some of the itinerant Igbo merchants, who travelled from one city to the other, were exposed to musical styles prevailing in such cities, especially Lagos and some major cities in West Africa. During this period (40s, 50s and 60s), the popular music styles prevalent in the urban cities were European dance forms like country music, ballroom dance, jazz music, soul, swing, waltz, and rock music. Radios and cinemas helped disseminate these foreign music forms or styles, and record plates and gramophones equally gave people the opportunity to have these songs in their possessions. The earliest popular musical style that was developed by the Igbo according to Omojola (2006) was palm-wine music, which was the combination of acoustic guitar, conga, and the thumb piano (ubo-aka). The music was performed in local palm-wine bars, which used to serve as recreational facilities for urban workers, and the lyrical content was basically Christian texts. Musicians who pioneered this musical genre within the period were Okonkwo Adigwe, G.T. Onwuka and Israel Nwoba.

Highlife, going by its description, implies a world or circumstance beyond the common or the ordinary. Therefore, highlife music within the socio-cultural context depicts the music for the higher class in the society, the elites, and basically not for the commoners' (Omojola, 2006: 53). Different literatures alluded to the fact that highlife music came from Ghana, where it originated to Nigeria in the early 30s through one of its prominent proponents - Emmanuel Teytey Mensah, who was regarded as the father of Highlife music (Ekwueme, 2004: Omojola, 2006: Emielu, 2011: Olusoji, 2011: Vidal, 2012: Obidike, 2012). The influence of 'Congo music' (from the Eastern part of Africa) on the Nigerian highlife music is also noticeable. This popular music genre is characterized by the use of string instruments, that is, Hawaiian guitars (Ekwueme, 2004: 37). Several Igbo 
highlife proponents and their counterparts from other ethnic groups were greatly influenced by 'Congo music' which was evident in their various stage performances. In his account, Bright Chimezie (personal communication, August 8, 2013) reveals that Igbo highlife in Nigeria evolved from two (2) distinct sources; musical styles of local instrumental ensembles (égwú èkpillì, égwú òdùmódù, égwú ògénè, and nkwà), and musical styles of fused western and local elements, I kwọ́kilikwọ́, also known as 'Native Blues' or 'counterpart to Juju music' (Ekwueme, 2004: 41). This has evidently been the most expressed musical style of Igbo highlife in Nigeria and has been popularised by different categories of Igbo musicians (old and young) over time. The most popular exponents of Ilkwọ́kilikwọ́ music include Osita Osadebe, Oliver de Coque, Sir Warrior, Kabaka, and Bright Chimezie. These musicians and a few others have been known for their musical ingenuity, creativity, vocal dexterity and lyrical prowess (Asobele, 2002: Ekweme, 2004: Obi, 2011). The younger musicians, on the other hand, have been noted in the modern era for their massive hybridisation of Igbo popular music through the highlife style (Okechukwu Ukeje, personal communication, August 9, 2013: Steve Onu, personal communication, August 1, 2013). In-depth description or discourse on Igbo highlife (or Ilkwọ́kilikwọ́) in terms of its structure and inherent forms (vocal and instrumental), is seriously lacking in the literature reviewed.

\section{Tagging and Classification of Igbo Popular Music}

Igbo popular music, like any other ethnic-based musical genre in Nigeria's music scene evolved through the process of acculturation and adaptation of musical styles from other world cultures through direct or indirect contact with them. These foreign musical styles, as advanced by Igbo popular music practitioners in Nigeria and the sources of their origin, are identified below:

\section{Highlife - Gold Coast, West Africa (E. T. Mensah)}

2. Congo (Soukous) Music - Democratic Republic of Congo, East Africa

3. Rock 'n roll, Jazz, Rhythm \& Blues, Rock - Europe and United States of America

Based on the above-mentioned information, it is pertinent to refer to Igbo Popular Music as a borrowed musical genre, and by extension christen it ' $\bar{E}-G W \bar{U} N$-NÙ-TÀ' [MMHLH], in 
Igbo language, meaning borrowed music; this comprises all manner of vocal and instrumental music, including dance forms.

Secondly, the advent of highlife music in Nigeria (as stated above) in the mid 1940s saw different ethnic groups advancing the musical style using ethnic or local elements, such as instrumentation, language, and costume. These kinds of activities created musical varieties among ethnic groups through their representatives thereby advancing and evolving different musical typologies or hybrids under highlife music. The Igbo version of this kind of highlife music is 'ìkwọ́killikwộ' or 'İkwọ́kìrìkwọ́,' also known as 'Igbo native blues,' which was massively advanced by a potpourri of older generation of Igbo popular musicians of note. The name 'İkwọ́kilikwộ' came as a descriptive term for the dexterity displayed in playing the electric lead guitar by the erstwhile popular musicians at recreational venues/centres. This study however, adopts this musical typology because it has been in existence and has played a very important role in the development of Igbo popular music in Nigeria from the past to the present. The following are basic features

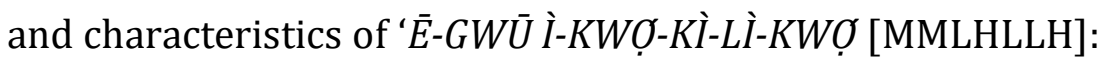

1. It incorporates the Congo music style of guitar playing into the West African highlife music. The guitar instruments are skilfully prominent during musical intros, interludes, and postludes by performing musicians.

2. The lyrical content of the music is usually philosophical emanating from social themes, such as love, patriotism, admonition, satire, praise singing, protest, etc. The use of mother tongue (Igbo) is crucial and paramount, especially when it is used to showcase ethnic identity and affiliations.

3. Several local instruments, such as ogene, ekwe, ocha, udu, ekpili, and okpokolo are occasionally fused with the Western instruments.

4. It is basically music for Igbo masses, enjoyed mostly by the old and the middleaged audience who understands the deep philosophical and poetic use of Igbo language by these musicians. This musical typology spans between the period of 1950-1990 and has enjoyed vast patronage and publicity over this period. 
The music is usually recorded on LPs, audio cassettes, and VCR, most of the time, live musical performances of musicians are equally recorded on these devices and sold. The recording of tracks or making of albums is done through the Digital/ Analogue process.

Thirdly, during the period of civil war in Nigeria (1967), most prominent cities, especially Lagos, witnessed the dwindling of performance of highlife music by musicians of Igbo extractions. Account given stated that most of the prominent Igbo highlife/ Ikwokilikwo musicians were forced to return to their home-towns in the then eastern region due to perceived hostilities by the indigenes, while some others were conscripted to the Biafrian Army to carry arms against perceived enemies of their state. During this period, new forms of popular music emerged, especially around the Western region, where musicians were seen to be performing more of Soul music and other musical styles such as Jazz, Pop, Disco, Reggae, Soukous (Congo music) and others. This notwithstanding, highlife (Ikwokilikwo) music still continued in the Eastern states unabated. These new forms or styles of popular music, which existed side by side with Ikwokilikwo music, were eventually embraced by a remarkable number of Igbo popular musicians, especially after the civil war in the 70s. These musical forms were, however, captured and tagged as ' $\bar{E}$ $G W \bar{U} O-G B \grave{A}-R \grave{A}-O-F \bar{U} \grave{U}^{\prime}$ [MMLLLMML], which means music of the 'new era' or 'new age'. The following are the perceived features of this musical typology:

1. The use of melodic instruments, such as electronic keyboard, lead and bass guitars, saxophone, and trumpet to enhance the rhythmic structure of the music. Both melodic and percussive instruments have equal participation within the song.

2. The lyrical contents are either adapted using foreign languages (English, French, Afrikaans, etc.) or performed using local dialects or its variants (code switching). The social themes are usually drawn from love stories, adventures, folk tales, political, religious, womanhood, marriage, and so on.

3. Musicians of this musical typology belong, for the most part, to the youth and middle-aged groups; they are well-educated, trained, exposed and well travelled. Some of them practice music on a part-time basis, while pursuing careers in accounting, banking, broadcasting, acting, engineering, etc. 
4. The audiences are made up of mixed ethnic backgrounds as musicians explore other local Nigerian dialects (Yoruba, Efik, Hausa, and Ibibio) in their songs for the purpose of propagating national unity among citizens.

5. The music is usually recorded on LPs, audio cassettes, and VCR. The recording of tracks or albums is done through the Digital/Analogue process.

Lastly, it can be observed that nowadays, Nigerian popular music has been eroded by diverse musical styles borne out of a syncretised process, that is, fusion of different musical styles (usually existing ones) in order to fit into the modern-day musical trends. The term 'Naija hip-hop' is used to represent the modern-day popular music by teeming talented young artists from different ethnic backgrounds. The predominant and common feature in the popular music scene of this present era is the act of re-arranging or remixing of old tunes by the younger generation of musicians through creative and innovative processes. Popular music styles, such as Rap, Rhythm and Blues, Hip-hop, Rock, Reggae, etc. (which are all adopted from Europe and America) were intertwined or fused with local derivatives, such as Highlife, Afro, Nkwa and Ekpili music, coming out with hybridised musical forms or typologies. This study intends to identify this hybridised musical typology within the Igbo popular music (Ēgwu Ńn̄ùtá) and christen it ' $\bar{E}-G W \bar{U} A ́-G W \bar{A}-R \bar{A}-O Q-G W \bar{A}$ [MMHMMHM], meaning a hybridised or syncretised musical typology. Listed below are the characteristics of this musical typology:

1. This kind of music is driven by the younger generation of musicians and equally enjoyed by the same age group. Most of the young artistes crave stage popularity and fast monetary gains more than achieving good quality in music and production.

2. The accompanying musical tones or sound in the music are digitally generated (both percussive and melodic). The music emphasises the use of strong, loud, and pulsating beat pattern usually supplied by side-kick drum, which is also synthesized. Vocal deliveries by these artistes are mostly enhanced using different applications programmed for such purposes.

3. The musical typology is characterised by code switching techniques, that is, using two or more languages (foreign \& local) within a particular song. For the purpose 
of this study, the primary language (Igbo), is fused with English, and Nigerian Pidgin English (NPE) respectively.

Thus, tagging or categorizing of musical typologies under Igbo popular (since 1960 to the present) is summarily represented in the diagram below:

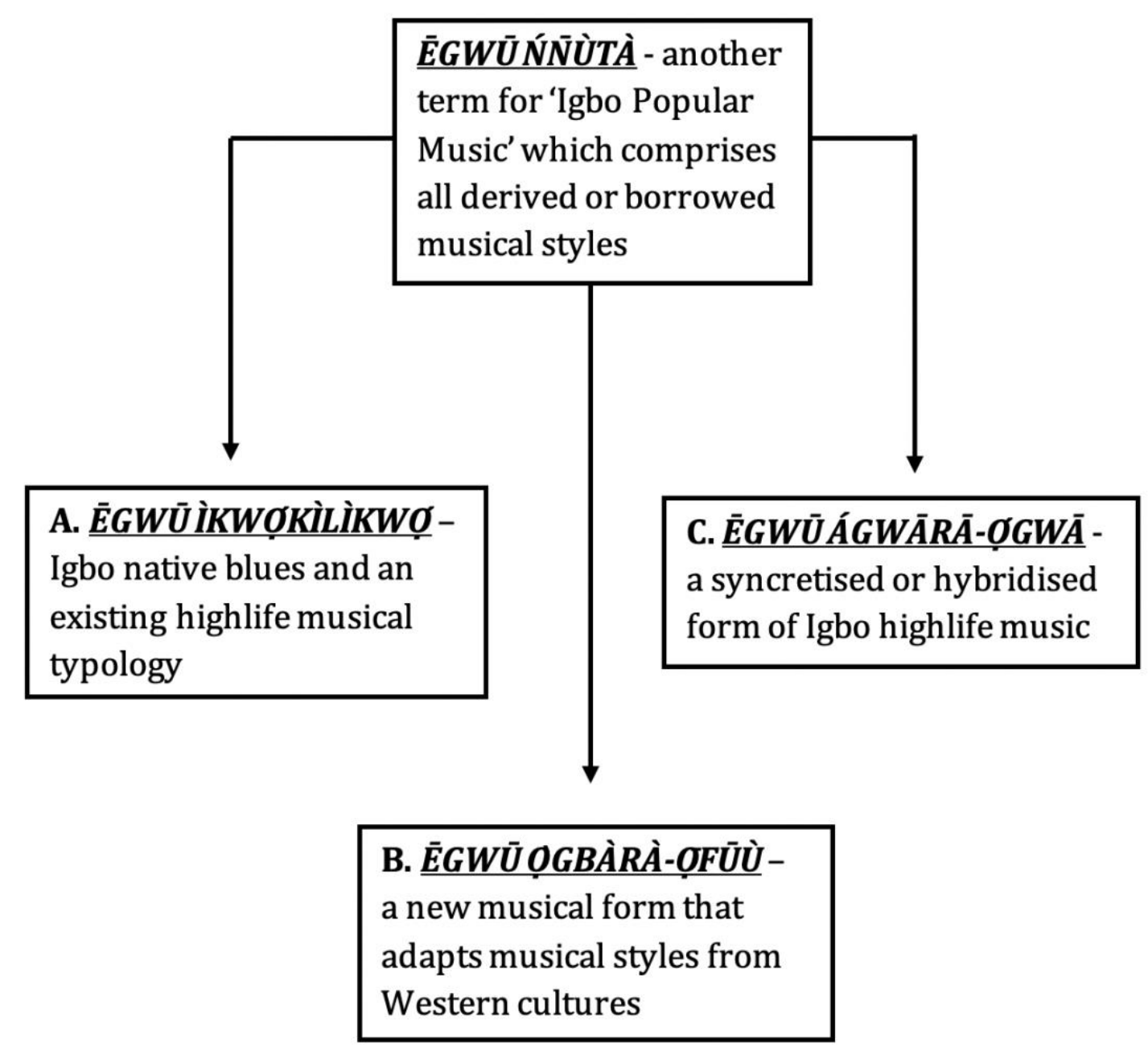

Figure 2. Diagram showing Igbo Popular Music Typologies

\section{Conclusion}

This study has, through its systematic analyses of Igbo popular music scenes in Nigeria, brought out salient features and characteristics of those music typologies and hybrids that were advanced by musicians of Igbo extractions. These aforementioned musical typologies traced from pre-independence era to the present, foreshadow the spirited efforts of Igbo popular musicians in advancing their cultural uniqueness through the 
instrumentality of popular music culture. The apparent scholarly dearth and disregard suffered by Igbo popular music, and by extension its highlife musical style, has been forthwith annulled by this singular effort. The overall development and advancement of the musical genre within the contemporary music scene in Nigeria has been given a positive boost by the in-depth analyses carried out, as well as the tagging of musical typologies (Égwú Nñùtá, Égwú İkwokillìkwo, Égwū ọgbàrà-ọfūù, and Égwú A gwàrà ogwa) of Igbo identity. The highest point of this achievement is, however, in the satisfaction that Igbo musical styles or typologies now have their identities embedded in the language, thereby distinguishing them from other ethnic based popular music genres.

\section{REFERENCES}

Adeola, Taiye. Shola. (2001). “Contemporary Nigerian popular music: A tool for national development". Nigerian Theatre Journal. 6(1): 80-85

Asobele, Timothy J. (2002). Historical trends of Nigerian indigenous and contemporary music. Lagos: Rothmed International Ltd.

Ekwueme, Lazarus E.N. (2004). Essays on the Theory of African music. Lagos-Nigeria: LENAUS Publishing Ltd.

Emielu, Austin. (2011). “The 'Culture' of Highlife Music". Ilorin Journal of Linguistics Literature \& Culture, 2:127-141.

Fiofori, Tam. (May 7th 2011). "Defining Nigerian Popular music", the Next Community Newspaper. Retrieved from www.nextcommunitynewspaper.com.

Nwoye, Chinwe M.A. (2011). “Igbo cultural and religious worldview: An insider's perspective". International Journal of Sociology and Anthropology, 3(9): 304-317.

Obi, Felix. (February 27th, 2005). "Whitter Nigerian Music?" Nigeria-world: Retrieved from www.naija.com 18th December, 2011.

Oikelome, Albert. (2001). Let's Talk about African Music, Shomolu Lagos; Glorious Hope Publishers.

Oikelome, Albert. (2012), "Feminine gender as perceived in Nigerian hip-hop culture: A sociological analysis". Music and Theatre Arts in Africa, Eds. Femi Shaka \& Mosunmola A. 
Omibiyi-Obidike: pp. 210-218, Ojo Lagos: Centre for Information, Press and Public Relations, Lagos State University.

Okafor, Richard C. (1997). "The Emergence of Neo-Traditional Forms in Contemporary Church Music in Eastern Nigeria", Music and Social Dynamics in Nigeria, Ed. Bode Omojola: pp. $126-140$

Olatunji, Michael (2007). "Yabis: A Phenomenon in the Contemporary Nigeria Music", The Journal of Pan African Studies, 1(9): 26-46

Olusoji, Stephen. (2011). "A discourse on the creative output of contemporary Nigerian musicians and their Place in the Global Community", Lagos Notes and Records, 17: 219226.

Omibiyi-Obidike, Mosunmola A. (2012). “Contemporary Popular Music in Nigeria”, Music and Theatre Arts in Africa, Eds. Femi Shaka \& Mosunmola.A. Omibiyi-Obidike: pp. 4-14, Ojo Lagos: Centre for Information, Press and Public Relations, Lagos State University.

Omojola Bode. (2006). Popular Music in Western Nigeria; Nigerian Themes, Styles and Patronage System, Ibadan: IFRA.

Osigwe, Chinedum Nathan (2016). "Musicological Analysis of Igbo Popular Music (19602010)". Ph. D Dissertation, University of Lagos, Akoka: Nigeria.

Scaruffi, Piero. (2003). "A Brief History of African Popular Music", History of Popular Music, Retrieved from www.scaruffi.com 18 ${ }^{\text {th }}$ September 2016.

Trant Jennifer. (2009). "Studying Social Tagging and Folksonomy: A Review and Framework", Journal of Digital Information, 10(1): 3-42.

Vidal, Augustine. (2012). From Classics to Pops: The Africanization of Western Institution. Paper presented at the Lagos State University, Ojo, Nigeria. 12 ${ }^{\text {th }}$ August, 2012. 